\title{
Pengaruh Pelaksanaan Akreditasi Puskesmas terhadap Kepuasan Pasien
}

\section{The Influence of Primary Health Care Accreditation on Patient Satisfaction}

\author{
Ratna Dwi Wulandari ${ }^{1 *}$, Ilham Akhsanu Ridho ${ }^{1}$, S. Supriyanto ${ }^{1}$, M. Bagus Qomarrudin ${ }^{2}$, \\ Nyoman Anita Damayanti ${ }^{1}$, Agung Dwi Laksono ${ }^{3}$, Alida Nella Fedelina Rassa ${ }^{4}$ \\ ${ }^{1}$ Departemen AKK Fakultas Kesehatan Masyarakat Universitas Airlangga \\ ${ }^{2}$ Departemen Pendidikan Kesehatan dan Ilmu Perilaku, Fakultas Kesehatan Masyarakat \\ Universitas Airlangga \\ ${ }^{3}$ Badan Penelitian dan Pengembangan, Kementerian Kesehatan RI \\ ${ }^{4}$ Program studi S2 AKK-Fakultas kesehatan Masyarakat, Universitas Airlangga \\ ("ratna-d-w@fkm.unair.ac.id)
}

\begin{abstract}
ABSTRAK
Sejak diberlakukannya kebijakan Jaminan Kesehatan Nasional (JKN), seluruh puskesmas di Indonesia wajib mengikuti akreditasi. Melalui akreditasi, diharapkan kualitas pelayanan puskesmas semakin meningkat, salah satu diantaranya dapat dilihat dari peningkatan kepuasan pasien. Penelitian ini dilakukan untuk menganalisis pengaruh akreditasi terhadap kepuasan pasien. Penelitian ini merupakan penelitian observasional dengan rancang bangun cross-sectional, yang dilakukan kepada 90 pasien puskesmas yang pernah berkunjung ke puskesmas sebelum dan sesudah akreditasi. Sampel diambil secara accidental sampai memenuhi kuota yang ditetapkan untuk tiap puskesmas. Uji Paired-Sample T Test dilakukan untuk melihat signifikansi perbedaan skor kepuasan sebelum dengan sesudah akreditasi. Hasil penelitian menunjukkan terdapat perbedaan skor kepuasan yang signifkan antara sebelum dengan sesudah akreditasi untuk dimensi mutu responsiveness, credibility, competence, communication, security, access, courtesy, understanding customer dan tangibles. Dimensi reliability tidak ditemukan perbedaan yang signifikan. Sedangkan khusus untuk dimensi understanding cutomer terjadi penurunan skor kepuasan sesudah akreditasi. Dengan demikian dapat disimpulkan bahwa akreditasi berpengaruh terhadap kepuasan pasien. Oleh karena itu, penting bagi puskesmas memperbaiki sistem pelayanannya terutama terkait dengan pemenuhan janji layanan yang telah ditetapkan sebagai sasaran mutu. Penyebaran informasi kepada masyarakat harus ditingkatkan, agar masyarakat menjadi mengetahui adanya akreditasi yang dijalankan oleh puskesmas.
\end{abstract}

Kata kunci : Akreditasi, kepuasan, mutu, pasien, puskesmas

\section{ABSTRACT}

Since the enactment of the National Health Insurance (JKN) policy, all Primary Health Care in Indonesia must follow accreditation. Through accreditation, it is expected that the quality of Primary Health Care services will increase, one of which can be seen from the increase in patient satisfaction. This study was conducted to analyze the effect of accreditation on patient satisfaction. The study was conducted on 90 Primary Health Care patients who had visited the Primary Health Care before and after accreditation. Data retrieval has been done crossectionally. The paired-sample T test was conducted to see the significance of differences in satisfaction scores before and after accreditation. The results showed that there were significant differences in satisfaction scores between before and after accreditation for the dimensions of responsiveness, credibility, competence, communication, security, access, courtesy, understanding customer and tangibles. In the reliability dimension no significant differences were found. While specifically for the cutomer understanding dimension there was a decrease in satisfaction scores after accreditation. Therefore, it is important for Primary Health Care to improve their service systems, especially related to fulfilling service promises that have been set as quality objectives. Dissemination of information to the public must be improved, so that the public becomes aware of the existence of programs run by the Primary Health Care, such as accreditation.

Keywords : Accreditation, satisfaction, quality, patient, primary health care 


\section{PENDAHULUAN}

Kualitas dapat diartikan sebagai tingkat kepatuhan terhadap standar yang telah ditentukan berdasarkan pengetahuan dan praktik yang dijalankan. ${ }^{1}$ Pentingnya kualitas dalam pelayanan kesehatan telah lama disadari oleh para pakar dan praktisi kesehatan dunia. WHO sebagai badan kesehatan dunia mengatakan bahwa sampai kapanpun kualitas dalam pelayanan kesehatan akan tetap relevan untuk dibahas, baik di negara maju maupun negara berkembang. ${ }^{2}$

Upaya peningkatan kualitas salah satunya dapat dilakukan melalui penerapan akreditasi, yaitu mekanisme penilaian eksternal yang digunakan untuk mengukut standar perbaikan mutu dalam pelayanan kesehatan. ${ }^{3}$ Proses akreditasi merupakan sebuah proses Quality Assurance yang berkaitan dengan aktivitas perbaikan mutu pelayanan kesehatan. ${ }^{4}$ Bagi industri pelayanan kesehatan di Indonesia, sebenarnya implementasi standar mutu bukan merupakan hal baru. Terhitung mulai tanggal 1 Januari 2014 pemerintah telah memberlakukan sistem Jaminan Kesehatan Nasional (JKN) sebagai salah satu bentuk Sistem Jaminan Sosial Nasional. Sistem Jaminan Sosial Nasional ini diselenggarakan melalui mekanisme Asuransi Kesehatan Sosial yang bersifat wajib (mandatory) berdasarkan Undang - Undang No. 40 Tahun 2004 tentang Sistem Jaminan Sosial Nasional. Peraturan Menteri Kesehatan No. 71 tahun 2013 menyebutkan bahwa Pelayanan Kesehatan Pada Jaminan Kesehatan Nasional bahkan disebutkan bahwa selain harus memenuhi berbagai persyaratan agar bisa bekerja sama dengan BPJS, fasilitas kesehatan tingkat pertama juga harus telah terakreditasi.

Pelaksanaan akreditasi membawa banyak perubahan di puskesmas. Perubahan organisasi bukanlah proses yang mudah karena anggota organisasi sudah terbiasa dengan kenyamanan dalam sistem kerja turun temurun. Proses perubahan dapat membawa dampak psikologis dan emosi karyawan yang akan mempengaruhi proses perubahan organisasi. ${ }^{4}$ Perubahan organisasi dapat dipengaruhi oleh banyak faktor, baik faktor internal maupun eksternal. ${ }^{5}$ Elemen internal organisasi yang berpengaruh diantaranya manajemen dan budaya organisasi. ${ }^{6}$

Penelitian time series yang dilakukan oleh
Devkaran dan Farrell menemukan bahwa meskipun akreditasi dilakukan dengan tujuan untuk meningkatkan kualitas organisasi pelayanan kesehatan, tetapi peningkatan ini tidak mampu dipertahankan selama siklus akreditasi 3 tahun. ${ }^{7}$ Jika tidak dikelola dengan baik, penerapan akreditasi puskesmas di Indonesia juga akan mengalami kegagalan yang sama. Jika hal ini yang terjadi, maka salah satu manfaat akreditasi yaitu meningkatkan kepuasan pasien, akan sulit dicapai. Penelitian terdahulu oleh Yousefinezhadi et. al, pada tahun 2017 di Rumah Sakit Iran menemukan bahwa meskipun rumah sakit mencapai nilai tinggi, tetapi masih memiliki masalah dengan kualitas dan keamanan dan pasien tidak puas dengan mereka. ${ }^{8}$ Hal ini menunjukkan bahwa beberapa organisasi mengalami kegagalan dalam meningkatkan kepuasan pasien meskipun telah melakukan beberapa perubahan dalam sistem layanannya.

Kondisi yang sama juga ditemui di puskesmas di Kota Surabaya. Sejak tahun 2015, secara bertahap Dinas Kesehatan Kota Surabaya memprogram beberapa puskesmasnya untuk mengikuti akreditasi. Sampai dengan akhir tahun 2017 sudah $46 \%$ puskesmas di Surabaya yang telah terakreditasi. Tetapi dari laporan survei Indeks Kepuasan Masyarakat diperoleh informasi bahwa kepuasan masyarakat terhadap pelayanan kesehatan di Surabaya di tahun 2017 mengalami penurunan dibandingkan tahun 2016. Terjadi penurunan Indeks Kepuasan dari 75.90 menjadi 71.76 atau menurun sebesar 4.14 poin, dari skor maksimal 100. Padahal seiring dengan pertambahan tahun diharapkan kepuasan masyarakat terhadap pelayanan kesehatan di Kota Surabaya dapat lebih ditingkatkan.

Belajar dari beberapa temuan penelitian terdahulu itulah, dirasakan penting untuk melakukan pengukuran dampak akreditasi puskesmas terhadap kepuasan pasien dan faktor yang mempengaruhinya. Oleh karena iu penelitian ini dilakukan dengan tujuan menganalisis pengaruh pelaksanaan akreditasi puskesmas terhadap kepuasan pasien. Hasil penelitian diharapkan dapat memberikan informasi mengenai aspek yang perlu diwaspadai karena rentan akan memunculkan ketidak puasan masyarakat.

\section{BAHAN DAN METODE}

Penelitian dilakukan di puskesmas Kota 
Surabaya Propinsi Jawa Timur yang dinyatakan telah lolos akreditasi. Penelitian dilakukan pada tahun 2016, yang mana pada awal tahun 2016 jumlah Puskesmas di Surabaya yang telah lolos akreditasi adalah 3 Puskesmas. Sehingga puskesmas yang dipilih sebagai lokasi penelitian adalah total puskesmas yang telah lolos akreditasi pada saat penelitian berlangsung. Penelitian ini merupakan penelitian observasional dengan rancang bangun cross-sectional. Pengambilan sampel puskesmas dilakukan secara total populasi, yaitu puskesmas di Surabaya yang telah lolos akreditasi saat penelitian dilakukan, sedangkan responden pasien diambil secara accidental sampling. Kriteria inklusi adalah pasien puskesmas yang pernah berkunjung ke puskesmas minimal 2 kali, dengan ketentuan 1 kunjungan saat puskesmas belum terakreditasi, dan 1 kunjungan saat puskesmas sudah terakreditasi. Pada pasien anak-anak atau lansia yang tidak memungkinkan diajak komunikasi, responden adalah pendamping pasien yang juga harus pernah mendampingi pasien berobat ke puskesmas minimal 2 kali sebelum dan sesudah akreditasi. Besar sampel adalah 90 pasien. Wawancara dilakukan kepada pasien yang memenuhi kriteria tersebut dengan alat bantu kuesioner.

Pengukuran kepuasan pasien dalam penelitian ini menggunakan 10 dimensi mutu menurut Parasuraman et. al, tahun 1985 yaitu terdiri dari reliability, responsiveness, credibility, competence, communication, security, access, courtesy, understanding customer, dan tangibles. ${ }^{9}$ Adapun indikator yang digunakan untuk mengukur masingmasing dimensi adalah sebagai berikut: a. Reliability: ketepatan jam buka dan kesesuaian proses layanan dengan alur layanan dan persyaratan yang ditetapkan; b. Responsiveness: kecepatan petugas menanggapi keluhan pelanggan dan ketanggapan petugas saat pelanggan membutuhkan; c. Competence: keterampilan petugas dalam menangani pasien dan keluasan wawasan petugas tentang masalah yang dihadapi pasien; d. Access: kemudahan akses secara fisik, waktu, dan biaya; e. Courtesy: kesopanan, penghargaan, dan keramahan petugas puskesmas dalam proses pelayanan; f. Communication: kejelasan dan kelengkapan informasi yang disampaikan petugas, serta kemudahan dalam memahami bahasa petugas; g. Credibility: kepercayaan pelanggan bahwa petugas Puskesmas memang layak untuk dipercaya karena mereka akan berusaha sebaik mungkin untuk pelanggannya; h. Security: penilaian tentang adanya risiko yang dapat membahayakan dirinya dari proses pelayanan di puskesmas; i. Understanding customer: upaya yang dilakukan oleh pemberi pelayanan untuk memahami kebutuhan pelanggan, j. Tangibles: kondisi gedung, kebersihan ruang, dan penampilan petugas.

Untuk melihat ada atau tidaknya dampak akreditasi puskesmas terhadap tingkat kepuasan pasien dilakukan uji beda T Sampel berpasangan, sehingga dapat dilakukan perbandingan tingkat kepuasan pasien sebelum dan sesudah pelaksanaan akreditasi puskesmas. Disamping itu juga dilakukan analisis terhadap berbagai dimensi mutu yang menurut pasien mengalami perubahan antara kondisi sebelum dengan sesudah pelaksanaan akreditasi.

\section{HASIL}

Responden dalam penelitian ini sebanyak 90 pasien yang berkunjung ke puskesmas minimal 2 kali sebelum dan sesudah puskesmas terak-

Tabel 1. Karakteristik Responden

\begin{tabular}{lc}
\hline \multicolumn{1}{c}{ Karakteristik } & $\mathbf{n}(\mathbf{\%})$ \\
\hline Umur & $7(7,8)$ \\
Remaja akhir (17-25 tahun) & $20(22,2)$ \\
Dewasa awal (26-35 tahun) & $19(21,1)$ \\
Dewasa akhir (36-45 tahun) & $21(23,2)$ \\
Lansia awal (46-55 tahun) & $23(25,5)$ \\
Lansia akhir / manula ( $>55$ tahun) & \\
Pendidikan & $20(22,2)$ \\
SD/sederajat & $17(18,9)$ \\
SMP/sederajat & $38(42,2)$ \\
SMA/sederajat & $5(5,6)$ \\
Diploma & $9(10,0)$ \\
Sarjana & $1(1,1)$ \\
Magister & \\
Kepemilikan asuransi & $32(35,6)$ \\
Umum & $35(38,9)$ \\
BPJS PBI & $20(22,2)$ \\
BPJS non PBI & $3(3,3)$ \\
Lain-lain & \\
Frekuensi kunjungan & $62(68,9)$ \\
$<10$ kali & $28(31,1)$ \\
$\geq 10$ kali & $9(10,0)$ \\
Jenis kelamin & \\
Laki-laki & \\
Perempuan & \\
\hline
\end{tabular}


Tabel 2. Penilaian Kepuasan pada Pelayanan Kesehatan Sebelum Akreditasi

\begin{tabular}{|c|c|c|c|c|c|c|c|c|c|}
\hline \multirow[t]{2}{*}{ Pernyataan } & \multicolumn{2}{|c|}{$\begin{array}{c}\text { Sangat Tidak } \\
\text { Puas } \\
\end{array}$} & \multicolumn{2}{|c|}{ Tidak Puas } & \multicolumn{2}{|c|}{ Puas } & \multicolumn{2}{|c|}{ Sangat Puas } & \multirow[t]{2}{*}{ Skor } \\
\hline & n & $\%$ & $\mathbf{n}$ & $\%$ & $\mathbf{n}$ & $\%$ & $\mathbf{n}$ & $\%$ & \\
\hline Reliability & 0 & 0 & 0 & 0 & 4 & 4,4 & 86 & 95,6 & 3.96 \\
\hline Responsiveness & 0 & 0 & 14 & 15,6 & 73 & 81,1 & 3 & 33,3 & 2.88 \\
\hline Competence & 0 & 0 & 1 & 1,1 & 8 & 8,9 & 81 & 90,0 & 3.89 \\
\hline Access & 0 & 0 & 0 & 0 & 4 & 4,4 & 86 & 95,6 & 3.96 \\
\hline Courtesy & 0 & 0 & 0 & 0 & 7 & 7,8 & 83 & 92,2 & 3.92 \\
\hline Communication & 0 & 0 & 1 & 1,1 & 6 & 6,7 & 83 & 92,2 & 3.91 \\
\hline Credibility & 0 & 0 & 6 & 6,7 & 83 & 92,2 & 1 & 1,1 & 2.94 \\
\hline Security & 0 & 0 & 7 & 7,8 & 79 & 87,8 & 4 & 4,4 & 2.97 \\
\hline Understanding customer & 0 & 0 & 0 & 0 & 9 & 10,0 & 81 & 90,0 & 3.90 \\
\hline Tangibles & 0 & 0 & 0 & 0 & 4 & 4,4 & 86 & 95,6 & 3.96 \\
\hline \multicolumn{9}{|c|}{ Mean komposit } & 3,63 \\
\hline
\end{tabular}

*Ket: 1-1,75: Sangat tidak puas; >1,75-2,5: Tidak puas; >2,5-3,25: Puas; >3,25-4: Sangat Puas

Tabel 3. Penilaian Kepuasan pada Pelayanan Kesehatan Setelah Akreditasi

\begin{tabular}{|c|c|c|c|c|c|c|c|c|c|}
\hline \multirow[t]{2}{*}{ Pernyataan } & \multicolumn{2}{|c|}{$\begin{array}{c}\text { Sangat Tidak } \\
\text { Puas } \\
\end{array}$} & \multicolumn{2}{|c|}{ Tidak Puas } & \multicolumn{2}{|c|}{ Puas } & \multicolumn{2}{|c|}{ Sangat Puas } & \multirow[t]{2}{*}{ Skor' } \\
\hline & $\mathbf{n}$ & $\%$ & $\mathbf{n}$ & $\%$ & $\mathbf{n}$ & $\%$ & $\mathbf{n}$ & $\%$ & \\
\hline Reliability & 0 & 0 & 0 & 0 & 1 & 1.1 & 89 & 98,9 & 3.99 \\
\hline Responsiveness & 0 & 0 & 6 & 6,7 & 48 & 53,3 & 36 & 40,0 & 3.33 \\
\hline Competence & 0 & 0 & 0 & 0 & 0 & 0 & 90 & 100,0 & 4.00 \\
\hline Access & 0 & 0 & 0 & 0 & 0 & 0 & 90 & 100,0 & 4.00 \\
\hline Courtesy & 0 & 0 & 0 & 0 & 1 & 1,1 & 89 & 98,1 & 3.99 \\
\hline Communication & 0 & 0 & 0 & 0 & 0 & 0 & 90 & 100,0 & 4.00 \\
\hline Credibility & 0 & 0 & 0 & 0 & 74 & 82,2 & 16 & 17,8 & 3.18 \\
\hline Security & 0 & 0 & 1 & 1,1 & 64 & 71,1 & 25 & 27,8 & 3.27 \\
\hline Understanding customer & 0 & 0 & 2 & 2,2 & 69 & 76,7 & 19 & 21,1 & 3.19 \\
\hline Tangibles & 0 & 0 & 0 & 0 & 0 & 0 & 90 & 100,0 & 4.00 \\
\hline \multicolumn{9}{|c|}{ Mean komposit } & 3,69 \\
\hline
\end{tabular}

*Ket: 1-1,75: Sangat tidak puas; >1,75-2,5: Tidak puas; >2,5-3,25: Puas; >3,25-4: Sangat Puas

reditasi. Karakteristik responden dalam penelitian ini terdiri dari umur, jenis kelamin, tingkat pendidikan, kepemilikan asuransi dan frekuensi kunjungan ke pelayanan kesehatan setelah adanya akreditasi. Data karakteristik responden disajikan dalam Tabel 1. Berdasarkan hasil penelitian, mayoritas responden tergolong dalam umur lansia akhir/manula yaitu umur $>55$ tahun $(25,5 \%)$. Jenis kelamin responden paling banyak adalah perempuan sejumlah 81 orang $(90 \%)$. Mayoritas responden memiliki tingkat pendidikan SMA/sederajat $(42,2 \%)$. Kepemilikan asuransi responden mayoritas be- rupa peserta BPJS PBI $(38,9 \%)$. Setelah akreditasi mayoritas responden melakukan kunjungan ke puskesmas kurang dari 10 kali $(68,9 \%)$.

Sebelum dilakukan pengukuran tingkat kepuasaan, pasien diwawancarai terlebih dahulu terkait pengetahuan tentang akreditasi puskesmas. Berdasarkan hasil penelitian, mayoritas responden $(84,4 \%)$ tidak tahu tentang akreditasi puskesmas. Sedangkan sisanya sebanyak 14 orang $(15,6 \%)$ tahu tentang akreditasi puskesmas. Data ini mengindikasikan bahwa akreditasi puskesmas masih belum diketahui oleh banyak orang. Mengingat masyarakat tidak paham tentang akreditasi, maka identifikasi kondisi sebelum dan sesudah akreditasi yang dilakukan dalam penelitian ini menggunakan hitungan tahun pelaksanaan akreditasi. Oleh karena puskesmas yang menjadi lokasi penelitian seluruhnya mengikuti penilaian akreditasi pada tahun 2015, maka masyarakat diminta menilai kondisi puskesmas sebelum tahun 2015 dan sesudah tahun 2015.

Kepuasan pasien pada penelitian ini di- 
Tabel 4. Hasil Uji Statistik Paired-Sample T Test Tiap Variabel

\begin{tabular}{lccc}
\hline \multicolumn{1}{c}{ Variabel } & $\begin{array}{c}\text { Skor kepuasan } \\
\text { sebelum akreditasi }\end{array}$ & $\begin{array}{c}\text { Skor kepuasan } \\
\text { sesudah akreditasi }\end{array}$ & Sig. \\
\hline Reliability & 3.96 & 3.99 & 0.181 \\
Responsiveness & 2.88 & 3.33 & 0.000 \\
Competence & 3.89 & 4.00 & 0.003 \\
Access & 3.96 & 4.00 & 0.045 \\
Courtesy & 3.92 & 3.99 & 0.033 \\
Communication & 3.91 & 4.00 & 0.011 \\
Credibility & 2.94 & 3.18 & 0.000 \\
Security & 2.97 & 3.27 & 0.000 \\
Understanding customer & 3.90 & 3.19 & 0.000 \\
Tangibles & 3.96 & 4.00 & 0.045 \\
\hline
\end{tabular}

ukur menggunakan kuesioner kepuasan pelayanan kesehatan dengan 10 dimensi, yaitu reliability, responsiveness, credibility, competence, communication, security, access, courtesy, understanding customer, dan tangibles ${ }^{9}$, yang selanjutya direstrukturisasi menjadi 5 dimensi reliability, emphaty, tangibles, responsiveness, dan assurance Hasil kepuasan pasien terhadap puskesmas sebelum melakukan akreditasi disajikan dalam Tabel 2.

Tabel 2 menunjukkan hasil mean komposit kepuasan pasien sebelum akreditasi sebesar 3,63. Hal ini menunjukkan bahwa mayoritas responden merasa sangat puas dengan pelayanan kesehatan di puskesmas sebelum akreditasi. Variabel dengan nilai tertinggi adalah communication, artinya komunikasi yang terjadi antara petugas kesehatan dan pasien puskesmas sebelum akreditasi sudah sangat baik. Sedangkan variabel dengan nilai terendah adalah responsivenes yang berkaitan dengan kecepatan dan ketanggapan petugas kesehatan dalam melayani pasien. Responsiveness memperoleh skor yang rendah karena masih ada $15,6 \%$ responden yang merasa kurang merasa puas dengan kecepatan petugas menanggapi kebutuhan pasien.

Pengukuran kepuasan responden setelah puskesmas terakreditasi dilakukan untuk melihat perbedaan kepuasan sebelum dan sesudah akreditasi. Tingkat kepuasan diukur dengan variabel dan pertanyaan yang sama dengan sebelum akreditasi. Namun, kepuasan yang dirasakan oleh responden dapat berbeda antara sebelum dengan sesudah akreditasi. Penilaian kepuasan responden terhadap pelayanan kesehatan pada puskesmas sesudah akreditasi disajikan pada Tabel 3. Berdasarkan
Tabel 3 dapat dilihat bahwa mean komposit kepuasan pasien sesudah akreditasi sebesar 3,69, yang artinya responden merasa sangat puas dengan pelayanan kesehatan di puskesmas sesudah akreditasi. Variabel dengan nilai tertinggi adalah tangibles. Mayoritas responden merasa puas terhadap variabel tangibles berupa kondisi ruangan dan penampilan petugas, sedangkan variabel dengan nilai terendah adalah credibility yang berkaitan dengan kesungguhan dan kemampuan petugas dalam melayani pasien.

Cara mengetahui perbedaan tingkat kepuasan pasien sebelum dengan sesudah akreditasi dapat dilakukan dengan 2 cara, yaitu secara deskriptif dengan membandingkan skor kepuasan sebelum dengan skor kepuasan sesudah akreditasi, serta melalui uji statistik paired-sample $T$ Test. Berdasarkan hasil perbandingan skor kepuasan sebelum dengan sesudah akreditasi diperoleh ada kesenjangan sebesar 0,07. Artinya, tingkat kepuasan pasien setelah akreditasi meningkat sebesar 0,07 point atau meningkat $7 \%$. Namun, jika dilihat per dimensi kepuasan, masih ada 1 dimensi yang mengalami penurunan kepuasan, yaitu dimensi understanding customer, yaitu menurun sebesar 0,71 point atau 7,1\%. Dimensi kepuasan yang mengalami peningkatan tertinggi adalah responsiveness.

Sementara itu dari hasil uji statistik paired-sample T Test diperoleh hasil bahwa semua dimensi kepuasan nilai signifikansinya $<0,05$ kecuali untuk reliability. Dengan demikian, dapat disimpulkan bahwa teerdapat perbedaan tingkat kepuasan responden antara sebelum dengan sesudah puskesmas terakreditasi pada dimensi respon- 
siveness, competence, access, courtesy, communication, credibility, security, understanding customer dan tangible.

Hasil uji $T$ test menunjukkan diantara 10 dimensi mutu, hanya dimensi reliability yang memperoleh nilai $\alpha>0.05$. Hal ini menunjukkan bahwa pada seluruh dimensi, kecuali reliability, terdapat perbedaan tingkat kepuasan antara sebelum akreditasi dengan sesudah akreditasi. Hal yang menarik adalah, ternyata ada satu dimensi yang mengalami penurunan skor kepuasan setelah akreditasi, yaitu pada dimensi understanding customer, dengan penurunan sebesar 0,71 point. Skor kepuasan sebelum akreditasi sebesar 3,90 yang berarti sangat puas, menurun menjadi 3,19 dengan kategori puas. Peningkatan skor kepuasan tertinggi ada pada dimensi competence, yang meningkat sebesar 0,11 .

\section{PEMBAHASAN}

Akreditasi dilaksanakan sebagai salah satu upaya untuk meningkatkan mutu pelayanan sebuah organisasi. Kementerian Kesehatan RI menyebutkan akreditasi merupakan salah satu upaya dalam menjamin peningkatan mutu pelayanan puskesmas. ${ }^{10}$ Melalui pelaksanaan standar akreditasi puskesmas, diharapkan memberikan manfaat tidak hanya bagi kepuasan pasien karena pelayanan yang diberikan sesuai standar sehingga aman, tetapi juga bagi kepuasan dan keamanan petugas kesehatan, karena pelayananan yang diberikan sesuai aspek legal dan pedoman tindakan medis, tetapi juga tetap memperhatikan kebutuhan dan ekspektasi masyarakat. Berdasarkan pernyataan tersebut, maka dapat ditarik kesimpulan bahwa salah satu ukuran keberhasilan akreditasi adalah kepuasan pasien.

Kepuasan pasien memberikan dampak pada keputusan pasien untuk menentukan pelayanan kesehatan yang akan digunakan. ${ }^{11}$ Kepuasan adalah konsep yang dinamis, artinya tingkat kepuasan masyarakat terhadap pelayanan puskesmas dari waktu ke waktu akan terus mengalami perkembangan. ${ }^{12}$ Oleh karena itulah meskipun puskesmas telah dinyatakan lolos akreditasi dan telah menerapkan standar pelayanan sesuai pedoman akreditasi, tetapi pengukuran kepuasan pasien tetap penting untuk dilakukan.

Faktor determinan yang paling bepengaruh pada kepuasan pasien adalah indikator kualitas pelayanan kesehatan. ${ }^{13}$ Di dalam literatur tentang manajemen mutu disebutkan ada beberapa ukuran yang bisa menggambarkan kualitas pelayanan kesehatan. ${ }^{11}$ Dimensi mutu pelayanan kesehatan yang banyak disitasi oleh para peneliti adalah 10 dimensi mutu layanan dari Parasuraman yang terdiri dari reliability, responsiveness, credibility, competence, communication, security, access, courtesy, understanding customer, dan Tangibles. ${ }^{9}$ Menurut Yarimoglu9 sekalipun teknik pengukuran mutu layanan yang dikembangkan oleh para ahli tersebut sudah terbilang cukup lama, tetapi masih terbukti efektif untuk digunakan hingga saat ini. Fatima et. al, dalam studi literaturnya menemukan hanya ada sedikit perbedaan dimensi kepuasan pasien terhadap pelayanan kesehatan antara negara maju dengan negara berkembang. ${ }^{14}$ Serqual sampai saat ini masih menjadi metode pengukuran kepuasan yang paling banyak digunakan oleh para peneliti. Salah satu contoh, penelitian oleh Respati menemukan penilaian terhadap dimensi reliability, assurance, tangible, empathy dan responsiveness berhubungan dengan puas atau tidaknya pasien. ${ }^{15}$

Pelaksanaan akreditasi puskesmas di Indonesia merupakan hal yang relatif baru. Kebijakan tentang wajib akreditasi puskesmas baru ditetapkan pada tahun 2014, melalui Peraturan Menteri Kesehatan Nomor 71 tahun 2013 tentang Pelayanan Kesehatan Pada Jaminan Kesehatan Nasional Pasal 6 ayat (2). Penelusuran terhadap penelitian terdahulu didapatkan informasi umum yang mengatakan bahwa kepuasan pasien dipengaruhi oleh akreditasi. ${ }^{16}$ Hasil yang sama diungkapkan oleh Yewen et. al, yang menemukan adanya hubungan antara status akreditasi puskesmas dengan tingkat kepuasan pasien di Kota Sorong Papua Barat. ${ }^{17}$ Hasil penelitian lainnya mengenai keuntungan dilaksanakannya akreditasi adalah adanya dokumentasi, adanya standar kualitas, menguatkan hubungan antara 5 pelayanan kesehatan dan stakeholder serta meningatkan kepuasan staff dan pasien. ${ }^{18}$ Namun, ulasan yang lebih mendalam tentang dimensi kepuasan yang dirasakan oleh pasien belum banyak ditemukan.

Hasil penelitian ini menemukan bahwa terdapat perbedaan tingkat kepuasan pasien sebelum dengan sesudah akreditasi untuk dimensi responsiveness, credibility, competence, communication, 
security, access, courtesy, understanding customer dan tangibles. Namun, khusus untuk variabel understanding customer skor setelah akreditasi justru menurun. Hal ini menunjukkan bahwa penerapan standar mutu akreditasi puskesmas terbukti mampu meningkatkan ketanggapan petugas, kredibilitas, kompetensi, komunikasi, keamanan pelayanan, keterjangkauan pelayanan, kesopanan, dan bukti fisik. Namun, khusus untuk variabel reliability dan understanding customer harus lebih diperhatikan karena dalam penelitian ini menunjukkan hasil yang kurang baik.

Terjadinya peningkatan skor kepuasan pasien pada dimensi responsiveness, credibility, competence, communication, security, access, courtesy, dan tangibles setelah akreditasi merupakan bukti adanya peningkatan kualitas pelayanan kesehatan di puskesmas. Di dalam standar akreditasi puskesmas disebutkan bahwa akreditasi dilakukan dengan tujuan memperbaiki kualitas pelayanan di puskesmas. ${ }^{10}$ Penerapan standar akreditasi dengan baik akan berdampak pada perbaikan seluruh dimensi mutu. Tetapi secara khusus bisa ditelaah adanya beberapa dimensi mutu yang terkait erat dengan standar akreditasi tertentu. Misalnya, bab IX standar akreditasi tentang peningkatan mutu klinis dan keselamatan pasien, yang di dalamnya mengatur tentang perencanaan, monitoring, dan evaluasi mutu layanan klinis, maka akan berpengaruh pada perbaikan dimensi responsiveness dan security. Demikian juga bab VII tentang layanan klinis yang berorientasi pasien dan bab VIII tentang manajemen penunjang layanan klinis, berpengaruh positif pada dimensi responsiveness, access, security, dan competence.

Salah satu kriteria bab I tentang penyelenggaraan pelayanan puskesmas berbunyi "akses masyarakat terhadap pengelola dan pelaksana pelayanan dalam pelaksanaan kegiatan memadai dan tepat waktu, serta terjadi komunikasi timbal balik antara pengelola dan pelaksana pelayanan Puskesmas dengan masyarakat”. Implementasi kriteria ini akan berdampak pada terjadinya perbaikan pada dimensi access, communication, dan cortesy. Sementara itu untuk dimensi tangibles banyak dibahas pada bab II kepemimpinan dan manajemen puskesmas. Demikian juga tentang ketenagaan puskesmas juga diatur secara mendalam pada bab II. Sehingga implementasi secara baik standar mutu pada bab II juga akan berpengaruh positif pada competence dan credibility pegawai puskesmas.

Dimensi reliability berkaitan dengan kemampuan puskesmas memenuhi apa yang telah dijanjikan, misalnya ketepatan jam buka dan kesesuaian proses layanan dengan dengan alur yang ditetapkan, termasuk didalamnya adalah pemenuhan standar waktu layanan yang tertera sebagai sasaran mutu. Salah satu fenomena yang banyak ditemui pasca diberlakukannya kebijakan Jaminan Kesehatan Nasional (JKN) adalah meningkatnya jumlah pengunjung puskemas. Peningkatan jumlah pengunjung ini jika tidak diantisipasi dengan baik akan berdampak pada tidak terpenuhinya dimensi reliability. Penelitian lain yang dilakukan oleh Hazfiarini dan Ernawaty juga menemukan hal yang sama sehingga dalam penelitian tersebut disarankan perlunya memperbaiki sistem antrian akibat meningkatnya jumlah pasien pada era BPJS kesehatan. ${ }^{19}$

Dimensi understanding customer dalam penelitian ini mengalami penurunan skor kepuasan. Salah satu penyebab yang diungkakan responden berkaitan dengan hal ini adalah adanya beberapa aturan yang menyebabkan beberapa kebiasaan yang sebelum era JKN dilakukan, tapi semenjak JKN tidak bisa dilakukan oleh pasien, misalnya permintaan rujukan. Sudah banyak diketahui bahwa pada era sebelum JKN pelaksanaan rujukan pasien lebih leluasa dibanding setelah JKN. Era JKN saat ini, BPJS kesehatan mengharuskan adanya rujukan berjenjang. Sebetulnya hal ini bukan dampak dari akreditasi puskesmas, tetapi karena penerapan akreditasi puskesmas bersamaan dengan penerapan kebijakan JKN, maka segala hal yang diatur dalam JKN turut menjadi hal yang dinilai oleh pasien. Alasan ini cukup logis, mengingat hasil pengukuran pengetahuan didapatkan bahwa sebagaian besar masyarakat tidak tahu tentang akreditasi puskesmas.

\section{KESIMPULAN DAN SARAN}

Pelaksanaan akreditasi puskesmas terbukti mampu meningkatkan kepuasan pasien pada dimensi responsiveness, credibility, competence, communication, security, access, courtesy, dan tangibles. Namun, ada beberapa dimensi mutu yang perlu diperhatikan, terutama dimensi relia- 
bility dan understanding customer. Oleh karena itu, puskesmas harus berusaha menata sistem pelayanannya terutama terkait dengan pemenuhan janji layanan sesuai dengan yang telah ditetapkan sebagai sasaran mutu. Penyampaian informasi kepada masyarakat juga perlu semakin ditingkatkan, agar masyarakat mengetahui adanya program atau aktivitas tertentu yang dijalankan oleh puskesmas, seperti akreditasi.

\section{UCAPAN TERIMA KASIH}

Ucapan terima kasih disampaikan kepada Universitas Airlangga, yang telah mendukung penelitian ini melalui kegiatan hibah penelitian di lingkungan Universitas Airlangga. Ucapan terima kasih juga disampaikan kepada Dinas Kesehatan Kota Surabaya yang telah memberikan kesempatan kepada penulis untuk terlibat sebagai fasilitator pada beberapa kegiatan persiapan akreditasi puskesmas di Kota Surabaya, sehingga mempermudah akses peneliti dalam melakukan penelitian terkait akreditasi puskesmas di Surabaya.

\section{DAFTAR PUSTAKA}

1. Kapoor BP. Why Quality in Healthcare? Medical Journal Armed Forces India [Online Journal]. 2011;67(3):206-208. Available at:http:// dx.doi.org/10.1016/S0377-1237(11)60040-3

2. Gupta KS, Rokade V. Importance of Quality in Health Care Sector: A Review. Journal of Health Management. 2016;18(1):1-11.

3. World Health Organization. Quality and Accreditation in Health Care Services: a Global review [Online]. Geneva: World Health Organization; 2003. Available from: http:// whqlibdoc.who.int/hq/2003/WHO_EIP_OSD_2003.1.pdf

4. Desveaux L, Mitchell JI, Shaw J, Ivers N. Understanding the Impact of Accreditation on Quality in Healthcare: A Grounded Theory Approach. International Journal for Quality Health Care. 2017:29(7);1-7.

5. Hoag BG, Ritschard H V., Cooper CL. Obstacles to Effective Organizational Change: The Underlying Reasons. Leadership and Organization Development Journal. 2002;23(1):615.

6. Avey JB, Wernsing TS, Luthans F. Can Positive Employees Help Positive Organizational
Change? Impact of Psychological Capital and Emotions on Relevant Attitudes and Behaviors. Journal of Applied Behavioral Science. 2008;44(1):48-70.

7. Devkaran, S., O'Farrell P. The Impact of Hospital Accreditation on Quality Measures: an Interrupted Time Series Analysis. BMJ Health Services Research. 2015:15(137);1-14.

8. Yousefinezhadi, Taraneh, Mosadeghrad, Ali Mohammad, Arab, Mohammad, Ramezani, Mozhdeh, Sari AA. An Analysis of Hospital Accreditation Policy in Iran. Iranian Journal of Public Health. 2017;46(10):1347-1358.

9. Yarimoglu, E.K. A Review on Dimensions of Service Quality Models. Journal of Marketing Management. 2014:2(2);79-93.

10. Kementerian Kesehatan RI. Standar Akreditasi Puskesmas. Jakarta: Direktorat Jenderal Bina Upaya Kesehatan, Kementerian Keseha$\tan$ RI; 2014.

11. Ferrand YB, Siemens J, Weathers D, Fredendall LD, Choi Y, Pirrallo RG, et al. Patient Satisfaction with Healthcare Services a Critical Review. Quality Management Journal. 2017;23(4):6-22.

12. Supriyanto, S., Wulandari RD. Manajemen Mutu Pelayanan Kesehatan. Surabaya: Health Advocacy; 2011.

13. Batbaatar E, Dorjdagva J, Luvsannyam A, Savino MM, Amenta P. Determinants of Patient Satisfaction: A Systematic Review. SAGE Journals. 2016;137(2):89-101.

14. Fatima I, Humayun A, Iqbal U, Shafiq M. Dimensions of Service Quality in Healthcare: a Systematic Review of Literature. International Journal Quality Health Care. 2019;31(1):1129.

15. Respati SA. Hubungan Mutu Pelayanan Kesehatan dengan Tingkat Kepuasan Pasien Rawat Inap di puskesmas Halmahera Kota Semarang Tahun 2014. [Skripsi]. Semarang Universitas Negeri Semarang; 2015. Available at: https:// lib.unnes.ac.id/20257/1/6411411220-S.pdf

16. Mirshanti F. Pengaruh Status Akreditasi Puskesmas, Faktor Sosial Ekonomi dan Jenis Asuransi Pasien terhadap Kualitas Pelayanan dan Kepuasan Pasien di Puskesmas. [Skripsi]. Surakarta: Universitas Sebelas Maret; 2017. [Online]. Available at: https://eprints.uns. 
ac.id/39498/1/S021508013 pendahuluan.pdf

17. Yewen MR, Korompis GEE, Kolibu FK. Hubungan antara Status Akreditasi Puskesmas dengan Tingkat Kepuasan Pasien di Kota Sorong Provinsi Papua Barat. Jurnal Kesehatan Masyarakat. 2018;7(5).

18. El-Jardali F, Hemadeh R, Jaafar M, Sagherian L, El-Skaff R, Mdeihly R, et al. The Impact of Accreditation of Public Healthcare Cen- ters: Successes, Challenges and Policy Implications as Perceived by Healthcare Providers and Directors in Lebanon. BMC Health Services Research. 2014;14(86).

19. Hazfiarini A, Ernawaty. Indeks Kepuasan Pasien BPJS Kesehatan terhadap Pelayanan Rumah Sakit Mata Masyarakat Jawa Timur. Jurnal Administrasi Kesehatan Indonesia. 2016;4(2):77-85. 